\title{
BILIRUBIN METABOLISM
}

\author{
Barbara H. Billing, Ph.D. \\ Department of Medicine, Royal Free Hospital, London, W.C.I
}

DURING the last ten years considerable advances have been made in our knowledge of the metabolism of bilirubin and thus in our understanding of the basic defects underlying jaundice, particularly in the newborn and in some types of familial hyperbilirubinæmia. These advances are due mainly to the characterization of 'direct' bilirubin as an ester glucuronide of bilirubin. Many of the classical concepts of bilirubin metabolism can therefore now be explained in chemical terms.

An exciting new development has been the production of radioactive bilirubin (Ostrow, Hammaker and Schmid, 1961; Grodsky, Carbone, Fanska and Peng, 1962); this tool has enabled the existence of an entero-hepatic circulation for bilirubin to be demonstrated and will doubtless help unravel many of the unsolved problems of bilirubin metabolism.

\section{Formation of bilirubin}

Most of the circulating bilirubin results from the catabolism of hæmoglobin in the reticuloendothelial system, particularly in the bone marrow, spleen and liver. The exact pathway of hæmoglobin breakdown first to biliverdin and then, after reduction, to bilirubin is still not clear. It is known that the administration of both hæmatin and protoporphyrin results in the formation of bilirubin but there is no conclusive evidence that either of these compounds is involved in the normal catabolism of hæmoglobin. In vitro studies have suggested that hæmoglobin may be degraded to bilirubin via choleglobin but its formation has not been demonstrated in vivo.

The studies of Gray, Neuberger and Sneath (1950), together with those of other investigators, have established that not all the bile pigment formed results from the breakdown of the red cells at the end of their life span. They used fæcal stercobilin as a measure of bile pigment production and after the administration of ${ }^{15} \mathrm{~N}$ glycine determined its specific activity at suitable time intervals (Fig. I). The ${ }^{15} \mathrm{~N}$ stercobilin timecurve had two peaks; the first occurred immediately following the glycine feeding while the second had a maximum about the r zoth day when the labelled red cells were breaking down. In the normal

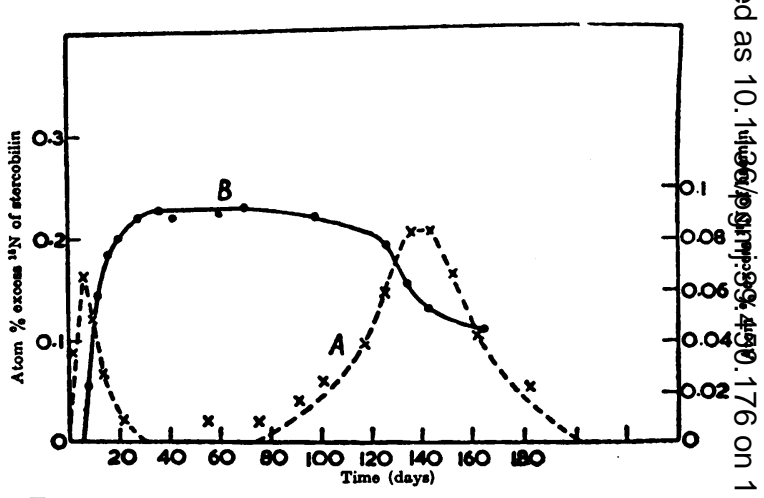

FIG. I. - ${ }^{15} \mathrm{~N}$ contents of hæm in samples (full line) and $D$ of stercobilin (dotted line) at various times after administration of glycine (12 g.) containing $3 \mathrm{I} .65 \%$ excess ${ }^{15} \mathrm{~N}$ to a normal subject (Gray and $\overrightarrow{0}$ others, 1950).

subject the first peak is responsible for approximately $10 \%$ of the pigment excreted but in diseases such as pernicious anæmia, congenital $\frac{\circ}{\circ}$ porphyria and thalassæmia $40-80 \%$ of the bile $\varrho$ pigment excreted may be due to this fraction. $\overrightarrow{\vec{B}}$ It was originally thought that this 'early sterco- 3 bilin' arose by direct synthesis from simple precursors such as aminolævulic acid or porphobilinogen. It is now considered, however, to be을 mainly erythrohæmopoietic in origin since this early incorporation of labelled glycine into sterco- 3 bilin is increased when erythrohæmopoiesis is stimulated. This erythrohæmopoietic stercobilin may be derived from three sources, namely, the immature red cells in the bone marrow (which are degrading hæmoglobin as well as synthesising it), 음 from hæm formed in excess of globin or from hæm formed by the destruction of newly formed $N$ red cells as soon as they reach the peripheral $N$ circulation. A very small amount of bilirubin could $N$ theoretically come from hæm pigments such as myoglobin or the cytochromes but there is no information regarding the role played by these proteins in bile pigment formation. The possibility $\stackrel{\Phi}{\oplus}$ of an hepatic origin of the early labelled stercobilin has been suggested by the work of WatsonJames and Abbott (1961) who found an increase in a patient with aplastic anæmia. 
Bilirubin is a lipid-soluble, non-polar pigment which gives an 'indirect' reaction in the presence of alcohol in the van den Bergh test. Prior to excretion in the bile, it is converted into a pigment which is water-soluble at a physiological $\mathrm{pH}$ and gives a 'direct' van den Bergh reaction with diazotised sulphanilic acid. Using chromotographic techniques Cole and Lathe (1953) were able to show that the properties of 'direct' bilirubin were not due to a different type of protein attachment but to an alteration in the chemical structure of the pigment. By means of partition chromatography (Cole, Lathe and Billing, 1954) (Fig. 2) or paper chromatography (Giovanneti, Maggiore and Vivaldi, I96I) it is possible to demonstrate that 'direct' bilirubin consists of two components (pigments I and II). The most polar pigment (pigment II) is the main pigment present in bile and together with an intermediate pigment (pigment I) is found in the icteric urine and sera of patients with obstructive jaundice, hepatitis and cirrhosis. The extreme instability of these pigments has so far prevented their isolation in a pure form. The structure of pigment II has therefore been established by characterizing the azo-pigment formed in the van den Bergh reaction; this pigment (azo-pigment B) is considerably more polar than azo-pigment $A$ and can be separated from it and other contaminants in diazotised bile by partition chromatography (Fig. 2), countercurrent distribution (Billing, Cole and Lathe, 1957) and paper chromatography (Schmid, 1957). The application of the latter two techniques has shown azo-pigment $B$ to be the ester glucuronide of azo-pigment A. Since two molecules of azopigment $A$ are known to be formed from one molecule of bilirubin it has been concluded that pigment II behaves similarly and is therefore an ester diglucuronide of bilirubin, the glucuronic acid radicals being linked to the carboxyl groups of the proprionic substituents of the molecule as indicated in Fig. 3. A similar conclusion was reached by Talafant ( $195^{6}$ ) as the result of experiments involving the electrophoresis of bile.

The structure of pigment I has been a more controversial matter. Since both azo-pigment $A$ and azo-pigment $B$ are formed from pigment $I$ in the van den Bergh reaction it seemed likely that the pigment is the monoglucuronide of bilirubin. However, if pigment $I$ is eluted from a chromatogram and then rechromatographed it has been observed that both bilirubin and pigment II appear on a second chromatogram (Billing, Cole and Lathe, 1957; Nosslin, 1960). This observation together with other studies (Gregory, I962; Weber, Schalm and Witmans, I963) gives support to the hypothesis that pigment $I$ is a labile equimolecular complex of bilirubin and bilirubin diglu-

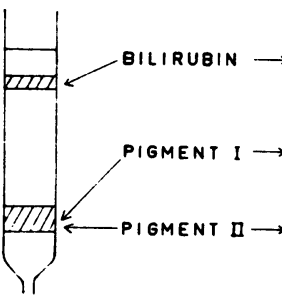

PH 6

$\mathrm{CHCl}_{3}-\mathrm{CCl}_{4}-\mathrm{CH}_{3} \mathrm{OH}$
BILE PIGMENTS
AZO PIGMENTS

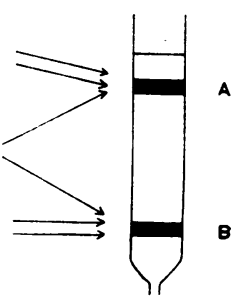

pH 6

n-BUTANOL
Fig. 2.-Behaviour of bile pigments and their diazo. products on reverse phase partition chromatograms. (Nosslin, 1960).

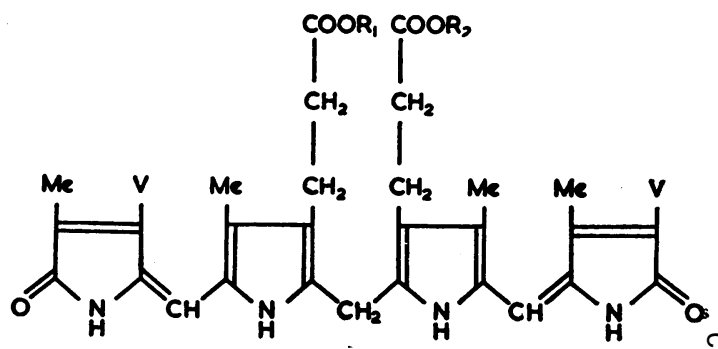

Fig. 3.-Structure of bile pigments (bilirubin, $R_{1}$ ando $R_{2}=H$; Pigment $I, R_{1}=$ glucuronyl and $R_{2}=H_{;}$ pigment II, $R_{1}$ and $R_{2}=$ glucuronyl; $M e=$ methy and $\mathrm{V}=$ vinyl).

curonide, and further investigations are now needed to determine the factors involved in its. formation.

It is generally accepted that over $80 \%$ of the bilirubin in bile is normally present as the glucuronide. Examination of chromatograms and the observation that mild alkali treatment does not convert all the 'direct' bilirubin in icteric serum or bile into bilirubin indicate that other conjugates may be present. Isselbacher and McCarthy (I959) by means of ${ }^{35} \mathrm{SO}_{4}$ tracer studies have demonstrated the presence of sulphate conjugates of bilirubin in the bile of rats, cats and humans. These findings have been confirmed in the rat by Schoenfield, Bollman and Hoffman (1962) who demonstrated that the sulphate conjugate of bilirubin is associated with pigment II but not with pigment I. Gregory and Watson (1962) have not, however, been able to demonstrate the presence of bilirubin sulphate in the bile of dogs or human subjects and question the assumption of Isselbacher and McCarthy that alkali-stable 'direct' bilirubin is identical with bilirubin sulphate. At present there is no evidence that defective conjugation of bilirubin as a glucuronide: 
in man can be compensated for by an appreciable increase in the excretion of bilirubin as a sulphate or some other conjugate.

\section{Biosynthesis of Bilirubin Glucuronide}

It has been demonstrated that uridine diphosphate glucuronic acid (UDPGA), and not glucuronic acid, is the glucuronyl donor necessary for the formation of bilirubin glucuronide (Fig. 4). The conjugating enzyme is a glucuronyl transferase (UDP-trans-glucuronylase) which is located in the microsomes; the evidence regarding the specificity of this enzyme is equivocal. Both the kidney and gastrointestinal tract as well as the liver contain an enzyme system capable of conjugating bilirubin. In the intact adult animal no satisfactory evidence has, however, been presented to indicate that conjugation of bilirubin takes place in any organ other than the liver. Hepatectomy in experimental animals results in the gradual accumulation of both bilirubin and a pigment which gives a 'direct' van den Bergh reaction and behaves chromatographically like pigment I. This pigment has been identified in the dog as bilirubin monoglucuronide (Schoenfield, Grindley, Foulk and Bollman, 1961) but the site of its formation under these abnormal conditions has not been established.

The ability of the fœtal and newborn liver to form bilirubin glucuronide is markedly reduced, due mainly to a deficiency of glucuronyl transferase activity rather than UDPGA. In the rat fotus the glucuronyl trransferase activity of the gastric mucosa is twice that of the adult liver (Stevenson and Dutton, 1962). The possibility that the gastric mucosa might be an important means of removing bilirubin in the fotus has been considered but seems unlikely in the light of recent studies using ${ }^{14} \mathrm{C}$ bilirubin in the guinea-pig fœtus. (Schenker, Dawber and Schmid, 1962) and the monkey fotus (Lester, Behrman and Lucey, r962), which showed that fotal bilirubin can be efficiently removed, after crossing the placenta, in the maternal bile.

\section{Enterohepatic Circulation of Bilirubin}

The experiments of Lester, Ostrow and Schmid (1961) in which ${ }^{14} \mathrm{C}$ bilirubin was administered intraduodenally to rats with bile fistulæ have clearly demonstrated that in the rat, bilirubin is absorbed from the intestine and then reappears in the bile. The absorption of unconjugated bilirubin appeared to be more rapid and quantitatively greater than that of conjugated bilirubin. It seems likely that conjugated bilirubin is first hydrolyzed to bilirubin and then absorbed as free bilirubin.

The existence of an enterohepatic circulation

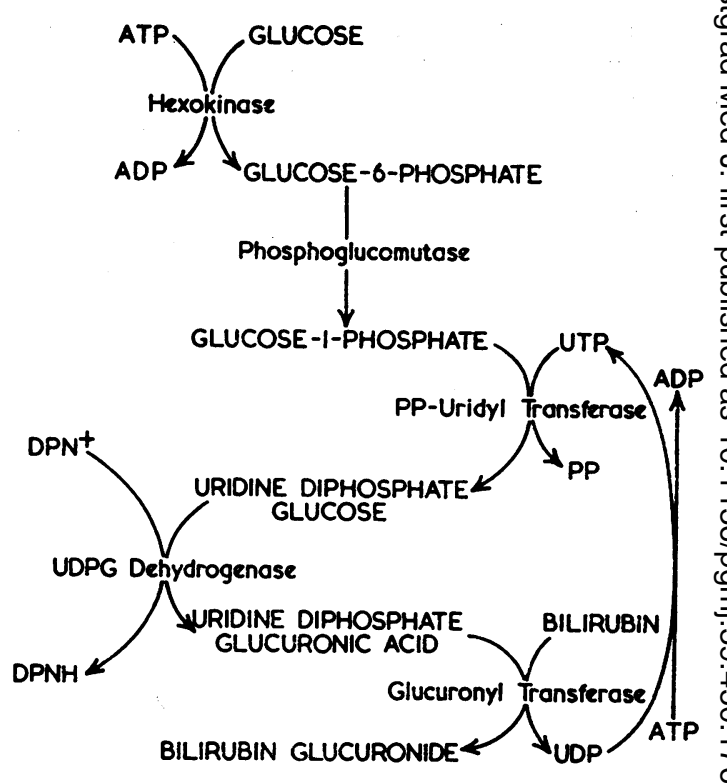

FIG. 4.-A possible mechanism for the conjugation of 0 bilirubin with glucuronic acid (Billing and Lathe, I958).

for bilirubin in man has been confirmed usin both bilirubin labelled with ${ }^{14} \mathrm{C}$ (Lester an Schmid, 1962) and bilirubin labelled with 15 (Gilbertsen, Bossenmaier and Cardinal, 1962). The significance of the enterohepatic circulation in normal man remains to be investigated. It may provide one of the reasons for the lack of correlation between the amount of pigment known to $\overrightarrow{\overrightarrow{0}}$ be formed from the breakdown of circulating red 3 cells and that found as stercobilin in the fæces. In patients with a compensated hyperbilirubinæmia due to a deficiency of glucuronyl transferase (Crigler-Najjar syndrome) and a homozygous strain of rats (Gunn rats) with the same deficiency, Schmid and Hammaker (r962) have found that unconjugated bilirubin can be both absorbed by the intestine and transferred from the plasma pool directly across the mucosa into the intestinal lumen. In the Gunn rats they were able to prevent $\frac{7}{0}$ its reabsorption by feeding cholestyramine resin, which has a high affinity for bilirubin, and in this $N$ way significantly reduced the serum bilirubin $N$ levels to 30 to $45 \%$ of the control values (Lester, Hammaker and Schmid, I962). The value of cholestyramine treatment in reducing jaundice in man remains to be assessed.

\section{Conversion of Bilirubin to Urobilinogen and Mesobilifuscin}

It has been well established that bilirubin, especially if in the conjugated form, is reduced 
by the bacterial flora in the intestine and colon to the urobilinogen group of pigments, which give the well-known Erlich's aldehyde reaction. These urobilinogens are readily dehydrogenated to give urobilin IX $\alpha$, stercobilin and d-urobilin, the relative amounts formed depending on the mobility of the intestinal contents and the rate of filling of the colon, as well as the efficiency of the bacterial flora. Watson and Weimer (1959) were unable to correlate the composition of the fæcal urobilin with the patient's condition and while urobilin IX $\alpha$ was the dominant pigment in some subjects, stercobilin predominated in others. The administration of broad-spectrum antibiotics may result in bilirubin rather than stercobilin being excreted in the fæces.

The presence of an enterohepatic circulation for urobilinogen was first postulated by McMaster and Elman (1927). They assumed that in liver disease re-excretion of urobilinogen into the bile was impaired and that instead, the pigment passed to the kidney and was excreted in the urine. Urobilinoid pigments are, however, not normally found in bile except in the presence of infection; if McMaster and Elman's hypothesis is correct this means that the pigment would have to be reconverted to bilirubin in the liver before it could be excreted in the bile which, for biochemical and structural reasons, seems unlikely. A critical re-examination of this problem with labelled stercobilin of high specific activity is required to establish whether urobilinogen, like bilirubin, after absorption from the intestine is re-excreted in the bile. Recent experiments by Kahan, Csernay and Varro (1962) have shown that the reabsorption of stercobilin from the isolated small intestine of the dog is dependent on the formation of a mucoprotein complex and suggest that the kidney may play some part in the conversion of urobilin to its respective urobilinogen prior to excretion in the urine.

It has been suggested that the discrepancies observed between urobilinogen excretion and hæmoglobin catabolism might be accounted for by the conversion of bilirubin or urobilinogen to dipyrrylmethenes such as mesobilifuscin. Studies by Gilbertsen and Watson (1962) support the view, however, that the naturally occurring fecal dipyrrylmethene pigments are anabolic rather than catabolic in origin.

\section{Bile Pigments in Plasma, Urine and Body Fluids}

At the serum bilirubin levels encountered in icteric plasma, regardless of the cause of the jaundice, virtually all the pigment is bound to albumin (Ostrow and Schmid, 1962). It is for this reason that attempts to reduce jaundice by dialysis have been for the most part unsuccessful. If however albumin is added to the dialysis fluid then it is possible for considerable quantities of bilirubin to be removed by intermittent peritoneal dialysis (Grollman and Odell, 1962).

Conjugated bilirubin is also bound to the plasma albumin but the type of pigment-proteincomplex formed is probably different (Klatskin and Bungards, 1956). It may also form a complex with phospholipids which can be extracted by shaking with ether (Charbonnier and Poungouras, 1959; Lucassen, 196r). This 'ether-soluble bilirubin' extraction test has been used to differentiate between malignant and nonmaligant biliary obstruction but according to Mertens and Croal (1960) is probably merely a measure of the degree of obstruction, as indicated by the high phospholipid level.

Small doses of bilirubin are quickly cleared from the plasma by the liver and then after storage and concentration are excreted into the bile at a slower rate. In the normal subject serum levels greater than $\mathrm{I} \mathrm{mg} / \mathrm{I} 00 \mathrm{ml}$ are rarely encountered and the bilirubin is almost entirely in the non-conjugated form. With raised levels of serum bile pigments, bilirubin will be stored in most of the tissues in the body, including the adipose tissue. It has been suggested that the staining of the tissues of the skin and muscle may be associated with their extravascular albumin content (Billing and Lathe, 1958). The differences in skin colour observed in infants with hæmolytic jaundice and adults with obstructive jaundice could be due to differences in tissue binding of bilirubin and conjugated bilirubin but these matters need to be investigated further.

Both unconjugated and conjugated bilirubin may be found in the lymph, ascitic fluid, pleural fluid and cerebrospinal fluid of the jaundiced subject. No correlation has been found between the bile pigment levels in the CSF and those in the plasma.

Bilirubin cannot usually be detected in the urine of normal subjects, or patients with an unconjugated hyperbilirubinæmia. In icteric urine both pigments I and II but not bilirubin are found. The level of conjugated bilirubin in the urine does not correlate well with that in the plasma and depends on the state of the disease process. In viral hepatitis, for example, bile pigments may appear in the urine even before the patient becomes clinically icteric but during convalescence no pigment will be found in the urine although the serum level may be as high as $6-8 \mathrm{mg} / 100 \mathrm{ml}$. Lack of pure specimens of conjugated bilirubin and suitable techniques for the quantitative determination of bile pigments in urine has prevented satisfactory renal clearance 
studies being carried out. It would appear that in the dog the pigments are excreted by the renal tubules, but there is no reliable evidence in man on this matter.

\section{Toxicity of Bilirubin and Kernicterus}

The yellow pigment that accumulates in the brain in kernicterus has been identified as unconjugated bilirubin. The toxic effects of bilirubin have therefore been studied and it has been shown that bilirubin has an inhibitory action on the oxygen consumption of brain tissue, particularly in the newborn. It has also been demonstrated that bilirubin is an inhibitor of hæm synthesis and that in rat liver and brain mitochondria it uncouples oxidative phosphorylation. According to Ernster (r96I) bilirubin behaves like a detergent in its action on mitochondria and causes swelling as well as inducing ATPase activity. With high concentrations of bilirubin the mitochondria are destroyed, and an enzyme may be released which will oxidise bilirubin to biliverdin. It is possible that such a reaction may be responsible for the presence of small amounts of biliverdin in the serum of patients with advanced liver disease.

The newborn animal is more susceptible to the toxic action of large doses of bilirubin than the adult animal (Rozdilsky, r96I). In some animals staining of the nervous tissue is only observed if there is previous brain damage by severe hypoglycæmia, anoxia or traumatic hæmorrhage. Whether previous damage as well as high concentrations of bilirubin are necessary for the development of kernicterus in man has not been established. Neither is it known why some parts of the brain (e.g. the corpora striata, the thalamus and the hippocampus) tend to become stained in the presence of high levels of plasma bilirubin while others do not. The part played by the blood-brain barrier has also still to be clarified. There is suggestive evidence that in the newborn the permeability is increased so that bilirubin passes more readily into the CSF and the brain.

Conjugated bilirubin, on the other hand, appears to be non-toxic. In the adult with severe jaundice these pigments are predominant and only on rare occasions are high levels of unconjugated bilirubin encountered. This is probably the main reason for the apparent absence of kernicterus in the adult.

\section{JAUNDICE}

On theoretical grounds increased concentrations of bilirubin in the plasma may result from one or more of the following causes (Fig. 5 ).

(I) An increased load of bilirubin.

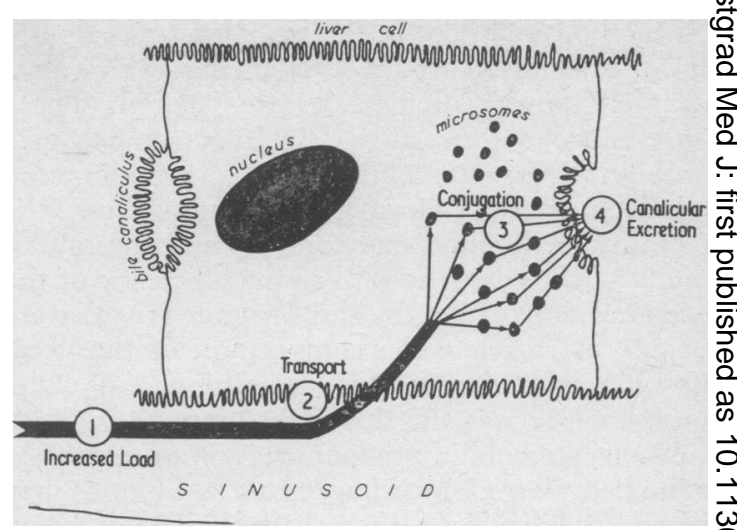

FIG. 5.- Jaundice could theoretically result from (I) an increased load of bilirubin; (2) defective uptake and transport within the liver cell; (3) defective 3 conjugation in the hepatic microsomes; (4) defec- $\omega$ tive canalicular excretion or a mechanical block in the bile duct system. (S. Sherlock (1962), Brit. ㅇ med. F., i, 1950).

(2) Defective uptake and transport within the $\stackrel{\text { 을 }}{-}$ liver cell.

(3) Defective conjugation of bilirubin in the hepatic microsomes.

(4) Defective canalicular excretion or mechanical block in the bile duct.

Although, in most instances, jaundice is not do to a single causative factor this may be the case in congenital hyperbilirubinæmia. Detailed studies of bile pigment metabolism in these disorders may, therefore, give some insight into the pathways of normal metabolism.

\section{r. Increased load of bilirubin Hamolytic disease}

An excessive release of hæmoglobin from the red cells may result in the normal daily production of $300 \mathrm{mg}$ of bilirubin being increased as much as six-fold. The capacity of the liver to excrete bilirubin is, however, greatly in excess of that normally required so that in hæmolytic disease the plasma bile pigment concentration rarely rises $\frac{5}{5}$ above $5 \mathrm{mg} / 100 \mathrm{ml}$. The main pigment in the $\frac{7}{0}$ plasma is unconjugated bilirubin so that bilirubinuria is not usually observed. Small amounts of $N$ conjugated bilirubin may be detected in the $N$ plasma but these will not exceed $15 \%$ of the total serum bilirubin concentration unless hepato- $\omega$ cellular damage has also occurred (Tisdale, Klatskin and Kinsella, 1959).

\section{Alternative pathways of bilirubin metabolism}

An overproduction of bilirubin can arise from sources other than the breakdown of mature red $\underset{\mathbb{D}}{\stackrel{D}{D}}$ cells. Israels, Suderman and Ritzman (1959) 
recently suggested that such a mechanism might be responsible for the unconjugated hyperbilirubinæmia they observed in four cases of jaundice, who had raised values of fæcal and urine urobilinogen excretion, in the presence of a normoblastic hyperplasia of the marrow. Determinations of the relative specific activities of hæm and stercobilin following the intravenous administration of 50 microcuries of ${ }^{2-14} \mathrm{C}$-glycine to one of these patients, who had an average daily excretion of $945 \mathrm{mg}$ stercobilin, indicated that at least $82 \%$ of this pigment was derived from sources other than the circulating red cells. Israels and Zipursky (1962) consider that this excess formation of bilirubin probably occurs in the bone marrow, either as a result of hæm catabolism or by a more direct anabolic pathway. They have called this 'shunt hyperbilirubinæmia' and consider that it represents a marked exaggeration of a normal pathway which is responsible for approximately I I \% of bile pigment production.

Excessive formation of bile pigments in the presence of minimal peripheral hæmolysis has also been cited by Arias (1962a) and Robinson, Vanier, Desforges and Schmid (1962) as a cause of chronic jaundice. The latter authors in their studies of the kinetics of bile pigment formation in a patient with thalassæmia minor, in whom there was marked evidence of 'ineffective erythropoiesis', were able to account for the pattern of stercobilin labelling by the greatly increased turnover of hæmoglobin in the bone marrow.

\section{Defects in hepatic uptake of bilirubin}

Almost nothing is known of the mechanism whereby bilirubin is transferred from the plasma via the sinusoids into the liver cell where it is actively transported to the microsomes for conjugation. A defect at some stage in this transport mechanism has been shown to occur in patients with 'Gilbert's Disease'. These comprise a heterogeneous group of benign disorders characterized by a mild unconjugated hyperbilirubinæmia of I-4 $\mathrm{mg} / \mathrm{roO} \mathrm{ml}$ (Billing and Williams, I962). Hepatic function tests are normal, except for an impaired bilirubin tolerance, and the composition of the bile and the fæcal urobilinogen excretion are also normal. Liver histology shows only minimal changes. Very occasional reports of reduced ${ }^{51} \mathrm{Cr}$ red blood cell survival times have been made in the presence of a normal reticulocyte count and a normal hæmoglobin concentration (Foulk, Butt, Owen and Whitcomb, 1959; Arias, 1962b) but there is no evidence of overt hæmolysis. No satisfactory evidence has so far been obtained which demonstrates a deficiency of glucuronyl transferase in these patients with Gilbert's disease. In the rarer type of patient with a plasma level greater than $8 \mathrm{mg} / 100 \mathrm{ml}$ it seems likely that the jaundice can be partly explained by an enzyme defect the extent of which appears to be related to the degree of jaundice.

\section{Defects in bilirubin conjugation Faundice in the Newborn}

Hepatic immaturity. In the newborn infant, unconjugated bilirubin will accumulate in the plasma until the necessary enzyme systems have developed to enable conjugation and excretion of the pigment to take place. It has been claimed that over $40 \%$ of newborn infants develop clinical jaundice of varying degrees of severity (Claireaux 1960). This is most likely to occur in premature infants who attain a higher degree of jaundice and remain jaundiced for a longer time than those with normal birth weights. It is only on rare occasions that the plasma bilirubin concentration exceeds $20 \mathrm{mg} / 100 \mathrm{ml}$, and, according to current practice, the need for an exchange transfusion has to be considered. This involves the removal of bilirubin not only from the plasma but also from the tissues. The administration of albumin prior to an exchange transfusion has therefore been suggested (Odell, r959), in order to obtain maximum transference of bilirubin into the vascular compartment. Although the procedure has still to receive clinical evaluation, results obtained from experimental work with puppies (Waters, I96I) would support the use of albumin as a therapeutic agent and encourage the use of whole blood rather than packed cells. Preliminary reports proposing that glucuronic acid might be useful in preventing kernicterus has not been substantiated: on theoretical grounds this is not surprising since it is UDPGA and not glucuronic acid which is the glucuronyl donor for the synthesis of bilirubin glucuronide.

It has been known for some time that bilirubin is readily destroyed by light and Cremer, Perryman and Richards (1958) and Ferreira, Cardim and Mellone ( 1960 ) have claimed that exposure of newborn infants to artificial light is a useful procedure for the treatment of jaundice of the newborn. The in vitro studies of Blondheim, Lathrop and Zabriskie (1962) suggest that the light treatment results in the formation of watersoluble derivatives which are not bound by albumin. Whether these derivatives have any deleterious effect on the infant needs to be investigated and proper control studies are necessary before this form of treatment can be generally accepted as advantageous.

It is difficult to assess the extent to which jaundice in the newborn constitutes a pathological condition or may be described as 'physiological jaundice'. In the following discussion of other 
factors influencing the development of jaundice in the newborn it is necessary to remember that there may be a pre-existing defect in conjugation and the concentration of unconjugated bilirubin in the plasma must be interpreted accordingly.

Hamolytic disease. In hæmolytic disease, whether due to $\mathrm{ABO}$ or $\mathrm{Rh}$ incompatibility, the dominant bile pigment in the plasma is bilirubin. This tends to rise more quickly and to greater heights in the premature infant, since in addition to hepatic immaturity the infant has to contend with a greatly increased production of bilirubin due to excessive hæmolysis. The jaundice accordingly lasts longer.

The plasma of infants with hæmolytic disease very occasionally contains conjugated bilirubin in the cord blood and in subsequent blood samples. If this develops within 24 hours of birth it is usually associated with severe anæmia and hepatosplenomegaly, and the presence of high values for serum aspartate transaminase suggests hepatocellular damage. Harris, Farrell, Shorter, Banner and Mathieson (1962) in their post mortem study of the liver histology of eight such infants could find no evidence of obstruction of the bile canaliculi by islands of extramedullary hæmopoiesis or swollen hepatic cells, regurgitation of bile by damaged liver cells or inspissation of viscous bile. The term 'inspissated bile syndrome' would therefore appear to have no real meaning in this context (Brent, 1962) and, as will be discussed later, the accumulation of conjugated bilirubin is probably due to a secretory defect. Since conjugated bilirubin does not appear to be toxic the serum level of unconjugated bilirubin rather than of total bilirubin should be the governing factor in assessing the need for an exchange transfusion in these patients.

Glucose-6-phosphate-dehydrogenase deficiency. An hereditary deficiency of the enzyme glucose-6phosphate dehydrogenase in the red cell can render it susceptible to hæmolysis by various agents including drugs and fava beans. This genetic defect may become apparent in the newborn reactor following the administration of sulfanilamide, naphthalene, primaquine or nitrofurantoin. Maternal medication with these drugs can result in this response occurring in the infant in utero.

Recent reports from Singapore (Smith and Vella, 1960), Greece (Doxiadis, Fessas and Valaes, I96I) and Sardinia (Panizon, I960) have indicated that in certain parts of the world a deficiency of glucose-6-phosphate dehydrogenase may be an important factor in the xtiology of severe neonatal jaundice in mature infants, in whom no blood group incompatibility has been recognized. Some of the jaundiced female infantso although non-reactors themselves, have beerf found to have fathers who are reactors. The severity of the jaundice, therefore, does no appear to be solely dependent on the degree of the enzyme defect. Fessas, Doxiadis and Valaes (1962) have found that in certain families the incidence of jaundice was greater than that found in 786 randomlyselected Greek male neonates $(2.92 \%$ which suggested that there are probably additiona genetic factors contributing to the development of severe jaundice. The jaundice disappears within w month of birth and does not reappear unless $\overrightarrow{5}$ suitable challenge is presented, such as the inges tion of fava beans; in this way the disease can bew differentiated from congenital non-spherocytiof hæmolytic anærnia. This condition appears to be्? an extremely unlikely cause of neonatal hyper bilirubinæmia in non-Mediterranean countries ine Europe.

Vitamin $K$. It is generally accepted that añ single dose of 2 to $5 \mathrm{mg}$. of a water-soluble vitamino $\mathrm{K}$ analogue is effective in preventing hæmorrhagic disease in the newborn and does not cause hyper $\rightarrow$ bilirubinæmia. If, however, the dosage is increased? then the likelihood of kernicterus developing is also increased (Bound and Telfer, 1956). TBiso toxic effect is apparent in menadiol sodis $\omega^{\omega}$ diphosphate (Synkavit) vitamin $\mathrm{K}_{1}$ and some the other analogues, but not in menaphthore-s dipotassium sulphate (Vikastab) (Corner, Berryo and Neale, I960). The mechanism wherebyo vitamin $K$ analogues cause jaundice is not welk understood. Vest (1958) has shown that the erythrocytes of premature infants given vitamin $\mathrm{K}$, in large therapeutic doses, have a shortened survival and in vitro studies with neonatal erythrocytes incubated with Synkavit have shown ao rapid decrease in the reduced glutathione content $\frac{3}{3}$. possibly due to interference in the regeneration of TPNH (Broberger, Ernster and Zetterström 1960).

Non-hamolytic Factors. Lathe and Walkero (1958) have demonstrated that in the later stages of pregnancy the plasma of the mother contains an unkown substance which will inhibit conjuga tion of bilirubin by rat-liver slices. Whether this substance normally crosses the placenta into the fœtal circulation and if so what its action in vivo would be, is unkown. It is, however, of interest thate studies in infants with severe 'Transient Familiaf Hyperbilirubinæmia' (Lucey and Driscoll, 196r) showed that the plasma of these infants and their mothers has this inhibitory action on in vitro conjugation of bilirubin. The relationship of the्षे inhibitor substance to the pathogenesis of the 
jaundice, which subsided within the first month of life has, however, not been established.

In a clinical trial of antibiotics in premature infants it was observed that the administration of sulfisoxazole reduced the concentration of plasma bilirubin and at the same time increased the incidence of kernicterus (Harris, Lucey and Maclean, 1958). Experiments with in vitro systems and genetically jaundiced Gunn rats (Johnson, Garcia, Figueros and Sarmiento, I96r) have shown that organic anions such as sulphonamides and salicylates compete with bilirubin for albumin binding sites. An inverse relationship exists between the blood level of the drug and the plasma bilirubin. The distribution of bilirubin in the body is therefore altered and there is an increase in the amount of pigment entering the brain which may cause kernicterus. These investigations emphasize the impossibility of assessing the success of a therapeutic agent in reducing jaundice in the newborn merely by determining the serum bilirubin level; evidence of an increased excretion of bilirubin must be obtained.

Another drug known to cause jaundice is novobiocin (Cox, Foltz, Raymond and Drewyer, I959); in the newborn it has been reported as causing a threefold increase in neonatal hyperbilirubinæmia (Sutherland and Keller, I96r). In vitro studies (Hargreaves and Holton, I962) suggest that novobiocin, which is excreted as a glucuronide, acts by competing with bilirubin for the very limited amount of glucuronyl transferase present in the newborn liver.

\section{Faundice in the Adult}

Crigler-Najjar Syndrome (Congenital non-hamolytic jaundice). In very rare instances the deficiency of glucuronyl transferase seen in the newborn may continue into adult life. This syndrome was first described by Crigler and Najjar (1952) who studied the children of three related families with serum levels of unconjugated bilirubin ranging from $12-45 \mathrm{mg} / 100 \mathrm{ml}$. Brain damage is often caused in the neonatal period so that many of these patients, if they survive, are to be found in mental hospitals. However, if neurological symptoms do not develop during early life then the prognosis is probably good (Childs and Najjar, 1956; Sugar, 1961) since the toxic effects of bilirubin are less marked in the adult. These patients have an impairment in their ability to form glucuronides with aglycones such as salicylates, n-acetyl p-amino phenol, menthol and tetrahydrocortisone (Schmid, 1960). Only trace amounts of bile pigments are found in the bile and fæcal urobilinogen excretion is low. In vitro studies have shown that there is a deficiency of hepatic glucuronyl transferase but not of UDPGA, which is responsible for their jaundice (Jervis, 1959; Szabo, Kovacs and Ebrey, 1962). In all other respects liver function appears to be normal and there is no evidence of hæmolytic disease.

The serum bilirubin levels remain relatively constant in these patients in spite of a normal rate of hæmoglobin breakdown and defective pigment excretion. Some alternative pathway for the removal of bilirubin must therefore be present which, although less efficient than the usual conjugating system since hyperbilirubinæmia occurs, is capable of maintaining a 'steady state' with respect to bilirubin. Schmid and Hammaker (1962) have used ${ }^{14} \mathrm{C}$ bilirubin to estimate the rate of turnover and the magnitude of the total miscible pool of bilirubin in a young boy with congenital non-hæmolytic jaundice. Most of the isotopic bilirubin appeared in the frces in the form of metabolites exhibiting properties different from those of the known bile pigments. Further work is needed to establish the site of breakdown of the bilirubir and the nature of the metabolites.

\section{Disturbances in hepatic excretion of bilirubin}

Obstructive jaundice and hepatocellular disease

Since over $90 \%$ of the pigments in hepatic bile occur as pigment II it would be expected that this would be the dominant pigment in the plasma of patients with extrahepatic biliary obstruction. If however the obstruction continues for some weeks then the proportion of pigment II in the serum will decline while that of pigment I will increase. A similar pigment pattern is then obtained to that found in the plasma of patients with parenchymal liver disease due to hepatitis or cirrhosis which has more pigment I than pigment II or bilirubin (Billing and Lathe, 1958). Hoffman, Whitcomb, Butt and Bollman (1960) examined the pigment patterns of 150 cases of jaundice and endeavoured to use them to differentiate between acute obstructive jaundice and hepatocellular disease. There was unfortunately a significant overlap between the two groups which prevents the procedure from being a useful diagnostic tool; it is not helpful in distinguishing between extra and intra-hepatic cholestasis.

Treatment with ACTH and corticosteroids has been used for the differential diagnosis of chronic jaundice with some degree of success. In infective hepatitis there is usually an immediate clinical improvement accompanied by a sharp decline in the plasma bilirubin level, which cannot be explained in terms of increased biliary excretion or a change in the renal excretion of bile pigments; the rate of red cell breakdown is also unchanged 
(Williams and Billing, 1961). In cases of intraand extra-hepatic obstructive jaundice and drug jaundice a favourable response is rarely seen. No satisfactory explanation has so far been put forward for the altered bile pigment metabolism following steroid therapy in hepatitis.

\section{Drug Faundice}

The first report of drug jaundice was by Hanger and Gutman (1940) in which 12 patients receiving intravenous arsphenamine for the treatment of syphilis became icteric after the second or third injection. Since then an ever-increasing number of drug reactions with jaundice due to intra-hepatic cholestasis has been described (Popper and Schaffner, I959). With many of these drugs such as chlorpromazine ('Largactil'), thiouracil, para-aminosalicylic acid, chlorpropamide and cetyl urea, the jaundice has been attributed to a hypersensitivity reaction. $1 \%$ of patients receiving chlorpromazine treatment develop frank jaundice together with increases in serum alkaline phosphatase and transaminases and also bromsulphthalein retention. Out of eight patients studied by Hoffman and others (1960) four had a pigment pattern similar to that seen with extra-hepatic obstruction, while the other four patients had a pattern suggestive of hepatocellular damage.

Anabolic agents, such as methyl testosterone and norethandrolone ('Nilevar') with a $\mathrm{C}_{17}$ alkyl substitution in the steroid molecule, may cause jaundice to appear late in the course of therapy, without symptoms of a hypersensitivity reaction. Abnormalities in the microvilli lining the biliary canaliculi have been reported following the administration of these drugs and it is thought that these may be responsible for the bile stasis (Schaffner, Popper and Perez, 1960). Experimental work with rats also supports the view that norethandrolone acts by interfering with the excretory function of the liver cell.

Another group of drugs occasionally causes a very severe type of jaundice, which is histologically and biochemically indistinguishable from viral hepatitis. This type of liver injury may follow the administration of the mono-amine oxidase inhibitors iproniazid ('Marsilid'), pheniprazine, $\beta$-phenyl isopropyl hydrazine, isocarboxazid ('Marplan') and phenalzine ('Nardil'). It has also been reported with iso-nicotinic acid, hydrazine, pyrazinamide, zoxazolamine and the oral hypoglycæmic agents metahexamide and tolbutamide.

Other drugs may cause jaundice as a result of direct hepatocellular damage, which affects both the conjugation and excretion of bilirubin. Drugs in this group include carbon tetrachloride, chlor oform, ethyl chloride, dichloro-diphenyltrichlorethane (D.D.T.) as well as muscarine,

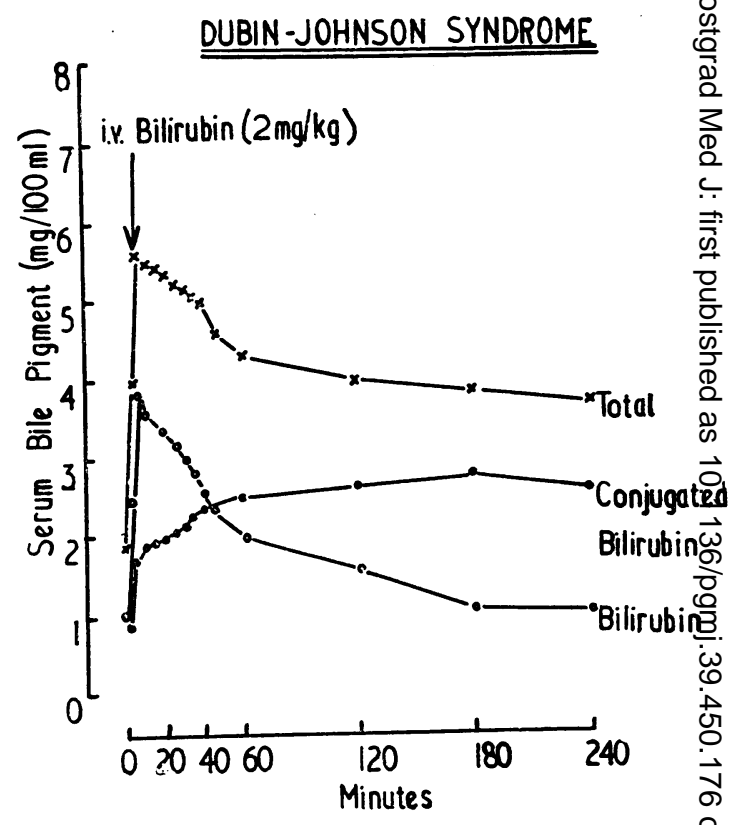

FIG. 6.-Effect of intravenous bilirubin (2 mg. kg.) $\stackrel{\circ}{\text { ำ }}$ the serum bile pigment concentration of a patient with the Dubin-Johnson syndrome.

metallic poisons, naphthalene and benzene de tives.

\section{Functional defects in excretion}

Defects in the excretory function of the livor need not necessarily be accompanied by any gross histological abnormality of the bile ducts. The accumulation of conjugated as well as unconjugated bilirubin suggests that the difficulty lies between the microsomes and the bile canaliculi. It appeaps to be developmental in origin but further investgations of the mechanism of pigment excretion are necessary to establish whether the defect $\frac{\hat{q}}{3}$ a structural or metabolic one.

It has been observed that in some infants wiô hæmolytic disease that the fall in level of plasma unconjugated bilirubin is preceded by a rise th the conjugated pigment concentration. Th indicates that the conjugating enzyme system ha developed satisfactorily but that the secretofy function of the liver cell is still inadequate (Harinis and others, 1962). This impairment in excretion may occasionally persist for several weeks and 婴 some patients appears to have a familial incidence (Jouvençeaux, Brizard, Michaud and Revol, I95\%; Billing, I96r).

In some cases of chronic non-hæmolytic jaundice in adolescents and adults conjugated $\vec{\Phi}$ well as unconjugated bilirubin is present in t 
plasma in spite of the absence of any histological evidence of an obstructive type of jaundice or hepatocellular lesion. When these patients are given an intravenous injection of bilirubin there is a rise in the plasma concentration of conjugated bilirubin at the time that the level of unconjugated bilirubin is falling, indicating a defect in hepatic excretion (Fig. 6). This excretory defect is not limited to bilirubin since there is retention of bromsulphthalein and other dyes after an intravenous dose. These patients also have difficulty in excreting cholecystographic contrast media. Other liver function tests are usually normal.

The patients can be divided into two groups dependent on the presence or absence of a yellowbrown granular pigment in the centrilobular regions, which give the liver a macroscopic black appearance. It is not thought that the pigment bears any relationship to the presence or intensity of the hyperbilirubinæmia (Wolf, Pizette, Richman, Dreiling, Jacobs, Fernandez and Popper, 1960). The patients with the lipochrome pigment are said to have the Dubin-Johnson syndrome (Dubin, 1958) while those without have the less common Rotor syndrome (Rotor, Manahan and Florentin, 1948; Schiff, Billing and Oikawa, 1959). An interrelationship appears to exist between the two syndromes since in a particular family some affected members may have the pigment, while others who are also jaundiced do not (Arias, r96r). Elucidation of the pathogenesis of these genetically determined disorders should give valuable information about the normal mechanism of excretion by the liver cell.

\section{REFERENCES}

ARIAS, I. M. (196I): Studies of Chronic Familial Nonhemolytic Jaundice with Conjugated Bilirubin in the Serum with and without an Unidentified Pigment in the Liver Cells, Amer. F. Med., 31, 5 IO.

(1962a): Chronic Unconjugated Hyperbilirubinæmia (UCH) with Increased Production of Bile Pigment not Derived from the Hemoglobin of Mature Circulating Erythrocytes, $\mathcal{F}$. clin. Invest., 4I, 134I.

(1962b): Chronic Unconjugated Hyperbilirubinæmia without Overt Signs of Hemolysis in Adolescents and Adults, F. clin. Invest., 4I, 2233.

Billing, B. H. (196I): The Role of Conjugation in the Excretion of Bilirubin, in 'Formation and Breakdown of Hæmoglobin'. Amsterdam and London: Elsevier.

- and Lathe, G. H. (1958): Bilirubin Metabolism in Jaundice, Amer. F. Med., 24, I I I.

- and Williams, R. (1962): Hepatic Transport of Bilirubin in Familial Hyperbilirubinæmia. American Association for the Study of Liver Disease. Meeting at Chicago.

- Cole, P. G., and Lathe, G. H. (1957): The Excretion of Bilirubin as a Diglucuronide giving the Direct van den Bergh Reaction, Biochem. $\mathcal{F}$., 65, 774.

Blondheim, S. H., LAThrop, D., and ZaBriskie, J. (1962): The Effect of Light on the Absorption Spectrum of Jaundiced Serum, F. Lab. clin. Med., 60, 31 .

Bound, J. P., and Telfer, J. P. (1956): Effect of Vitamin K Dosage on Plasma-bilirubin Levels in Premature Infants, Lancet, $\mathrm{i}, 720$.

Brent, R. L. (1962): Persistent Jaundice in Infancy, F. Pediat., 6r, i 1 I.

Broberger, O., Ernster, L., and ZetTerstrom, R. (1960): Oxidation of Human Hæmoglobin by Vitamin $\mathrm{K}_{3}$, Nature (Lond.), 188, 316.

Charbonnier, A., and Poungouras, P. (1959): Les Ether-solubilités de la Bilirubine, Rev. int. Hépat., 9, 589.

ChILDS, B., and NAJJAR, V. A. (1956): Familial Non-hæmolytic Jaundice with Kernicterus. A Report of 2 Cases without Neurologic Damage, Pediatrics, 18, 369.

Claireaux, A. E. (1960): Neonatal Hyperbilirubinæmia, Brit. med. Y., i, I 528.

Cole, P. G., and Lathe, G. H. (I953): The Separation of Serum Pigments giving the Direct and Indirect van den Bergh Reaction, F. clin. Path., 6, 99.

,-- , and Billing, B. H. (1954): Separation of Bile Pigments of Serum, Bile and Urine, Biochem. F., 57, 5 I4.

CoRNer, B., Berry, E., and NeALe, A. V. (I960)! Hyperbilirubinæmia in Premature Infants and the Effect of Vitamin K Lancet, $\mathbf{i}, 7 \mathrm{I} 5$.

Cox, R. P., Foltz, E. L., Raymond, S., and Drewyer, R. (1959): Novobiocin Jaundice, New Engl. Y. Med., 26r, 139.

Cremer, R. J., Perryman, P. W., and Richards, D. H. (1958): The Influence of Light on the Hyperbilirubinæmia of Infants, Lancet, i, 1094.

Crigler, J. F., and NajJar, V. A. (1952): Congenital Familial Nonhemolytic Jaundice with Kernicterus, Pediatrics, I0, I69.

Doxiadis, S. A., Fessas, R., and Valaes, T. (196I): Glucose-6-phosphate Dehydrogenase Deficiency, Lancet, i, 297.

Dubin, I. N. (1958): Chronic Idiopathic Jaundice: A Review of 50 Cases, Amer. F. Med., 24, 268.

ERNSTER, L. (196I): The Mode of Action of Bilirubin on Mitochondria. Transactions of Panel on Kernicterus. 9th International Congress, of Pediatrics, Montreal, p. 174. Ed. A. Sass-Kortsak. Toronto: University Press.

Fessas, R., Doxiadis, S. A., and Valaes, T. (1962): Neonatal Jaundice in Glucose-6-Phosphate Dehydrogenase-deficient Infants, Brit. med. F., ii, 1359.

Ferreira, H. C., Cardim, W. H., and Mellone, O. (1960): Phototherapy. A New Therapeutic Method in Hyperbilirubinæmia of the Newborn, $\mathcal{F}$. Pediat. (Rio), 25, 347.

Foulk, W. T., ButT, H. R., Owen, C. A., and WhitcomB, F. F. (1959): Constitutional Hepatic Dysfunction (Gilbert's Disease): Its Natural History and Related Syndromes, Medicine, 38, 25.

Gilbertsen, A. S., Bossenmaier, I., and CARDinal, R. (1962): Enterohepatic Circulation of Unconjugated Bilirubin in Man, Nature (Lond.), 196, 141. 
, and Watson, C. J. (1962): Studies of the Dipyrrylmethene ('Fuscin') Pigments. III. The Variable Fate of Bifir rubin depending upon Conjugation and other Factors, $\mathcal{Y}$. clin. Invest., 4I, IO4I.

Giovannetti, S., MAGgioRe, Q., and Vivaldi, G. (1961): Separation by Paper Chromatography of Various Fractions Conjugated Bilirubin occurring in Human Bile, Ital. F. Biochem., 10, 88.

Gray, C. H., Neuberger, A., and Sneath, P. H. A. (1950): Studies in Congenital Porphyria Incorporation of ${ }^{15} \mathrm{~N}$. Stercobilin in the Normal and in the Porphyric, Biochem. F., 47, 87.

Gregory, C. H. (1962): Studies of Conjugated Bilirubin. III. 'Pigment I'. A Complex of Conjugated and Free Bils rubin. In the press.

- and Watson, C. J. (1962): Studies of Conjugated Bilirubin. II. Problem of Sulfates of Bilirubin 'In Vivo' and 'In Vitro', Ұ. Lab. clin. Med., 60, 17.

Grodsky, G. M., Carbone, J. V., Fanska, R., and Peng, C. T. (1962): Tritiated Bilirubin: Preparation and Physi logical Studies, Amer. Y. Physiol, , 203, 532.

Grollman, A. P., and Odell, G. B. (1962): Removal of Bilirubin by Albumin during Intermittent Peritoneal Dialysi New Engl. F. Med., 267, 279.

HANGER, F. M., and GútMan, A. B. (1940): Postarsphenamine Jaundice Apparently Due to Obstruction of the Intrơ⿱⺈ hepatic Biliary Tract, F. Amer. med. Ass., 115, 263.

Hargreaves, T., and Holton, J. B. (I962): Jaundice of the Newborn due to Novobiocin, Lancet, i, 839.

Harris, R. C., LuCEY, J. F., and MACLEAN, R. J. (1958): Kernicterus in Premature Infants Associated with Low Con centrations of Bilirubin in the Plasma, Pediatrics, 21, 875.

Harris, L. E., Farrell, F. J., Shorter, R. G., BanNer, E. A., and Mathieson, D. R. (1962): Conjugated Seruigh Bilirubin in Erythroblastosis Fetalis: Analysis of 38 Cases, Proc. Mayo Clin., 37, 574.

Hoffman, H. M., Whitcomb, F. F., But, H. R., and Bollman, J. L. (1960): Bile Pigments of Jaundice, F. clint. Invest., 39, $\mathrm{I} 32$.

Isselbacher, K. J., and McCarthy, E. A. (1959): Studies on Bilirubin Sulfate and Other Non-glucuronide Conjugates of Bilirubin, $\mathcal{F}$. clin. Invest., 38,645 .

IsRaels, L. G., Suderman, H. J., and Ritzman, S. E. (1959): Hyperbilirubinæmia due to an Alternate Path of Bilirubin Production, Amer. F. Med., 27, 693 .

-, and ZIPURSkY, A. (1962): Primary Shunt Hyperbilirubinæmia, Nature (Lond.), 193, 73.

JeRvis, G. A. (1959): Constitutional Non-hæmolytic Hyperbilirubinæmia with Findings Resembling Kernicterus Arch. Neurol. Psychiat., 81, 55.

Johnson, L., Garcia, M. L., Figueros, E., and Sarmiento, F. (196I): Kernicterus in Rats Lacking Glucuronyit Transferase, A.M.A.f. Dis. Child., ror, 322.

Jouvenceaux, A., Brizard, C. P., Michaud, D., and Revol, L. (1959): Treatment of Hæmolytic Disease of the Newborn, due to $\mathrm{Rh}$ Immunization, Brit. med. $\mathcal{Y}$., ii, 336.

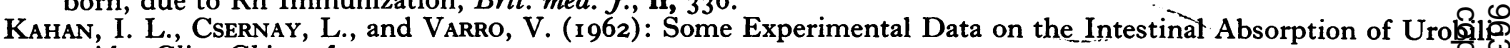
noids, Clin. Chim. Acta., 7, 392.

KLATSKIN, G., and BUNGarDS, L. (1956): Bilirubin-protein Linkages in Serum and their Relationship to the van Bergh reaction, $\mathcal{F}$. clin. Invest., $35,537$.

Lathe, G. H., and Walker, M. (1958): Inhibition of Bilirubin Conjugation in Rat Liver Slices by Human Pregnancy and Neonatal Serum and Steroids, Quart. F. Exp. Physiol., 43, 257.

Lester, R., and Schmid, R. (1962): The Mechanism of Intestinal Absorption of Bilirubin, $\mathcal{~}$. clin. Invest., 41, I379.

-, Ostrow, J. D., and Schmid, R. (1961): Enterohepatic Circulation of Bilirubin, Nature (Lond.), 192, 372.

, Hammaker, L., and Schmid, R. (1962): A New Therapeutic Approach to Unconjugated Hyperbilirubinæmia Lancet, ii, 1257.

_- Behrman, H., and Lucey, J. F. (1962): Placental Transfer of Bilirubin-C ${ }^{14}$ in the Monkey. American Associatio for study of Liver Disease Meeting at Chicago.

LuCASSEN, J. (196I): The Diazö Reaction of Bilirubin and Bilirubin-glucuronide. Ph.D. thesis, University of Utrecht

LuCEY, J. F., and DrisColl, T. J. (1961): Physiological Jaundice Re-examined. Transactions of panel on Kernicterus. 9th International Congress of Pediatrics, p. 29. Montreal, ed. A. Sass-Kortsak. Toronto: University Press.

McMaster, P. D., and Elman, R. (1927): Urobilin Physiology and Pathology, Ann. intern. Med., r, 68. Mertens, G. A., and Croal, A. E. (1960): Ether-extractable Pigment in Icteric Serum: A Simple and Useful Test if
the Investigation of Jaundice, Canad. med. Ass. F., 83, 1148 .

Nosslin, B. (1960): The Direct Diazo Reaction of Bile Pigments in Serum, Scand. F. clin. Lab. Invest., 12, Suppl. 4\% ODELL, G. B. (1959): The Dissociation of Bilirubin from Albumin and its Clinical Implications, $\mathcal{~}$. Pediat., 55, 265.

Ostrow, J. D., Hammaker, L., and Schmid, R. (1961): The Preparation of Crystalline Bilirubin-C14, f. clin. Invest 40, 1442.

- and Schmid, R. (1962): The Binding of Bilirubin-C14 to Human Serum Proteins, Clin. Res., 10, 191.

Panizon, F. (1960): Erythrocyte Enzyme Deficiency in Unexplained Kernicterus, Lancet, ii, ro93.

PopPer, H., and SchafFNER, F. (1959): Drug Induced Hepatic Injury, Ann. intern. Med., 5I, 1 230.

RoBINSON, S., VANIER, T., DESFORGES, J. F., and Schmid, R. (1962): Jaundice in Thalassemia Minor: A Consequence of 'Ineffective Erythropoiesis', New Engl. Y. Med., 267, 523.

Rozdilsky, B. (196I): Toxicity of Bilirubin in Adult Animals, Arch. Path., 72, 8I.

Rotor, A. B., Manahan, L., and Florentin, A. (1948): Familial Non-hemolytic Jaundice with Direct van den Berg@ Reaction, Acta med. philipp, 5, 37 .

Schaffner, F., Popper, H., and PEREZ, V. (1960): Changes in Bile Canaliculi Produced by Norethandrolone: Electrof Microscopic Study of Human and Rat Liver, 7 . Lab. clin. Med., 56, 623.

Schenker, S., Dawber, N. H., and Schmid, R. (1962): Disposition of Bilirubin in the Fetus, f. Lab. clin. Med., 60, 101 50

Schiff, L., Billing, B. H., and Orkawa, Y. (1959): Familial Non-hemolytic Jaundice with Conjugated Bilirubin in the $\mathbb{e}^{+}$ Serum, New Engl. F. Med., 260, 315.

Schmid, R. (1957): The Identification of Direct Reacting Bilirubin as Bilirubin Glucuronide, F. biol. Chem., 229, 881.

- (1960): Hyperbilirubinæmia. 'The Metabolic Basis of Inherited Disease', edited by J. B. Stanbury, J. B. Wyn gaarden, and D. S. Frederickson. New York: McGraw Hill. 
, and Hammaker, L. (1962): Trans. Ass. Amer. Physcns. In press.

Schoenfield, L. J , Grindley, J. H., Foulk, W. T., and Bollman, J. L. (I96I): Identification of Extrahepatic Bilirubin Monoglucuronide and Its Conversion to Pigment 2 by Isolated Liver, Proc. Soc. exp. Biol. (N.Y.), ro6, 438

- , Bollman, J. L., and Hoffman II, H. N. (1962): Sulfate and Glucuronide Conjugates of Bilirubin in Experimental Liver Injury, $\mathcal{F}$. clin. Invest., 41, 133.

Sмith, G. D., and Vella, F. (1960): Erythrocyte Enzyme Deficiency in Unexplained Kernicterus, Lancet, i, I 133.

Stevenson, T. H., and Dutton, G. J. (1962): Glucuronide Synthesis in Kidney and Gastrointestinal Tract, Biochem. $\mathcal{F}$, 82, 330 .

Sugar, P. (196r): Familial Nonhemolytic Jaundice, Arch. intern. Med., ro8, r2 r.

Sutherland, J. M., and Keller, W. H. (196I): Novobiocin and Neonatal Hyperbilirubinæmia, Amer. F. Dis. Child., IOI, 447.

Szabo, L., Kovacs, Z., and Ebrey, P. (1962): Congenital Non-hæmolytic Jaundice, Lancet, i, $55_{2}$.

Talafant, E. (1956): Properties of the Bile Pigment giving a Direct Diazo Reaction Nature (Lond.) 178, 312.

Tisdale W. A., Klatskin, G., and Kinsella, E. D. (1959): The Significance of the Direct Reacting Fraction of Serum Bilirubin in Hemolytic Jaundice, Amer. F. Med. 26, 214.

VEST, M. (1958): Der Einfluss von Naphthohydrochinonderivaten (wassloslichen Vitamin K Ersatzproparoten, Synkavit) auf Erythrocytenabbau und regeneration bei Frutogeburten und auf das Glukuronidbildungstermögen der Leber, Schweiz. Med. Wschr., 88, 1969.

Waters, W. J. (196I): The Protective Action of Albumin in Bilirubin Toxicity in Newborn Puppies. 'Transactions of Panel on Kernicterus' p. 219. 9th International Congress of Pediatrics, Montreal, ed. A. Sass-Kortsak. Toronto: University Press.

Watson, C. J., and Weimer, M. (r959): Composition of the Urobilin Group in Urine Bile and Fæces and the Significance of Variations in Health and Disease, F. Lab. clin. Med. 54, I.

Watson-James, G., and Аввот, L. D. (I96r): Abstracts of the Vth International Congress in Biochemistry, p. 529. Oxford: Pergamon.

Weber, A. R., Schalm, L., and Witmans, J. (1953): Bilirubin Monoglucuronide (Pigmənt I); A Complex, Acta. med. Scand., 173, I9.

Williams, R. S., and Billing, B. H. (I96I): Action of Steroid Therapy in Jaundice, Lancet. ii, 392.

Wolf, R. L., Pizette, M., Richman, A., Dreiling, D. A., Jacobs, W., Fernandez, O., and PopPer, H. (i 960 ): Chronic Idiopathic Jaundice: A Study of 2 Afflicted Families, Amer. $\mathcal{F}$. Med., 28, 32. 